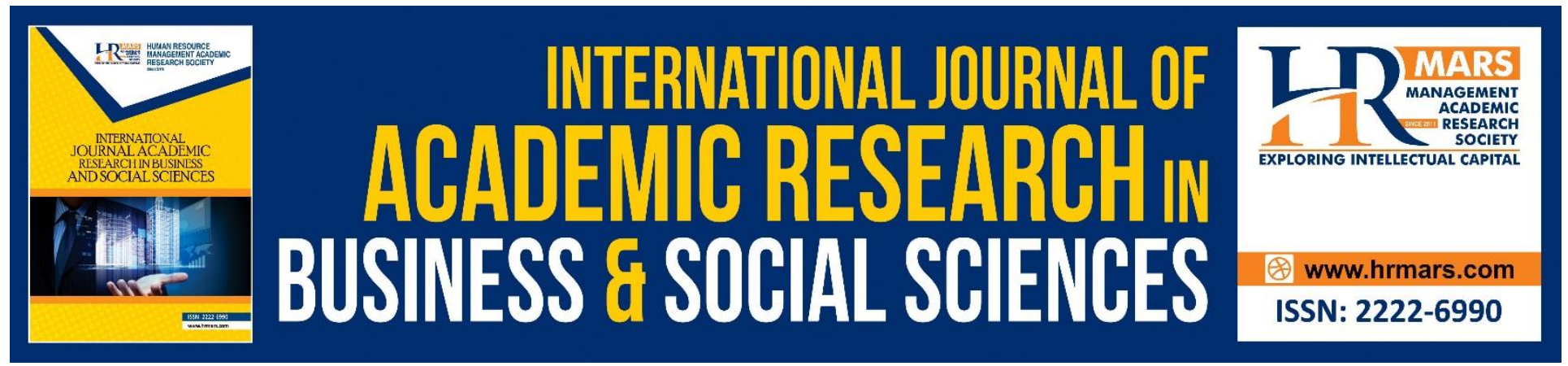

\title{
Open and Distance Learning (ODL) During Movement Control Order (MCO): Conceptualising the Relationships between Self-Efficacy, Learning Motivation and Performance of Higher Learning Education Students
}

Hasnizawati Hashim, Nor Aziah Abd. Kadir, Fazreena Mansor \& Muhammad Zainuddin Mohamed Azudin

To Link this Article: http://dx.doi.org/10.6007/IJARBSS/v10-i8/7530 DOI:10.6007/IJARBSS/v10-i8/7530

Received: 06 May 2020, Revised: 14 June 2020, Accepted: 10 July 2020

Published Online: 25 August 2020

In-Text Citation: (Hashim et al., 2020)

To Cite this Article: Hashim, H., Kadir, N. A. A., Mansor, F., \& Azudin, M. Z. M. (2020). Open and Distance Learning (ODL) During Movement Control Order (MCO): Conceptualising the Relationships between Self-Efficacy, Learning Motivation and Performance of Higher Learning Education Students. International Journal of Academic Research in Business and Social Sciences, 10(8), 258-269.

Copyright: (c) 2020 The Author(s)

Published by Human Resource Management Academic Research Society (www.hrmars.com)

This article is published under the Creative Commons Attribution (CC BY 4.0) license. Anyone may reproduce, distribute, translate and create derivative works of this article (for both commercial and non-commercial purposes), subject to full attribution to the original publication and authors. The full terms of this license may be seen at: http://creativecommons.org/licences/by/4.0/legalcode

Vol. 10, No. 8, 2020, Pg. 258 - 269

http://hrmars.com/index.php/pages/detail/IJARBSS

JOURNAL HOMEPAGE

Full Terms \& Conditions of access and use can be found at http://hrmars.com/index.php/pages/detail/publication-ethics 


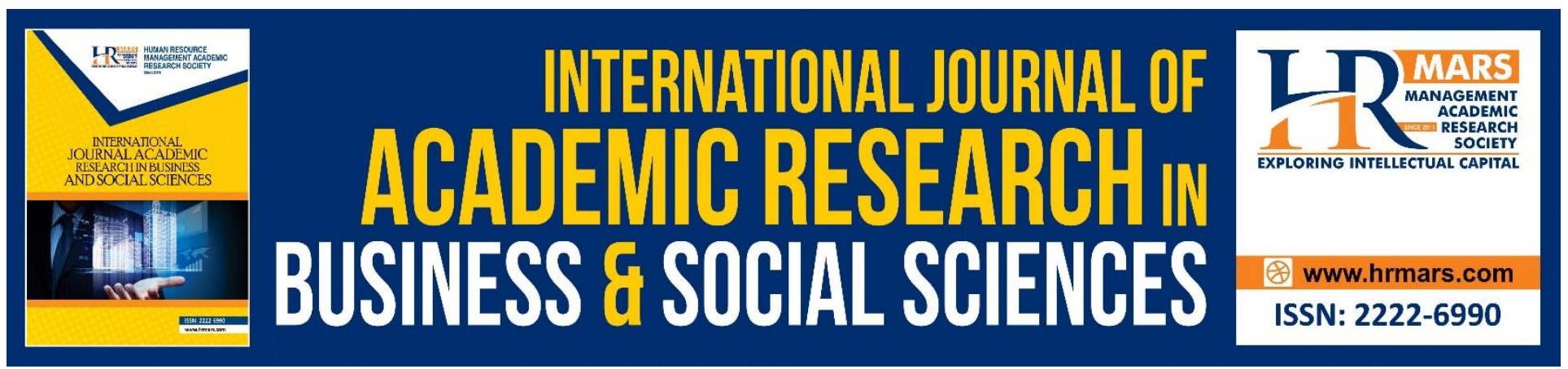

\title{
Open and Distance Learning (ODL) During Movement Control Order (MCO): Conceptualising the Relationships between Self-Efficacy, Learning Motivation and Performance of Higher Learning Education Students
}

\author{
Hasnizawati Hashim, Nor Aziah Abd. Kadir, Fazreena Mansor \& \\ Muhammad Zainuddin Mohamed Azudin \\ Universiti Teknologi MARA Pahang, Raub Campus, Pahang, Malaysia
}

\section{Abstract}

The coronavirus disease (COVID-19) has caused an unprecedented impact to the whole world, including the learning style used at the tertiary education level. Universities are urged to apply open and distance learning (ODL) during the movement control order (MCO) in pursuing their lessons. Despite advancements in technology, ODL during MCO has its unexpected consequences based on some technical and personal challenges that students have encountered. This paper proposes examining students' academic performance based on the Social Cognitive theory (SCT). To better explain this model, the MCO period was used as the context of this study to bring new insight on education implementation and acceptance. This paper concludes with implications for future research and applications for academicians.

Keywords: COVID-19, Higher Learning Education, Movement Control Order, Open and Distance Learning, Students' Performance.

\section{Introduction}

The coronavirus disease (COVID-19) is an infectious disease caused by a newly discovered coronavirus. It infects people with respiratory illnesses, and no vaccine has yet to be found. People are shocked and afraid of this highly contagious virus which is easily spread and can sustain contact between people. Thus, it has caused an unprecedented impact to the whole world. Many difficult decisions and actions have been taken by authorities around the world to protect their countries in order to curb the infection and control the mortality rate. Malaysia was among the first countries to implement a Movement Control Order (MCO) or Restriction Order in the South East Asian region (Khor, Arunasalam, Azli, Khairul-Asri,\& Fahmy, 2020). The Prime Minister of Malaysia held a live nationwide telecast on 16 March 2020 to announce the implementation of the MCO on 18 March 2020 (Coronavirus Disease (COVID-19) in Malaysia, 2020). Under the MCO, the public is prohibited 
INTERNATIONAL JOURNAL OF ACADEMIC RESEARCH IN BUSINESS AND SOCIAL SCIENCES Vol. 10, No. 8, 2020, E-ISSN: 2222-6990 @ 2020 HRMARS

from mass gatherings or events including religious, sports, social, and cultural activities. Schools and universities were also closed. Therefore, all university students were asked to vacate their residential colleges and go back to their hometowns. Due to the limited time given, some students were not able to go home and were thus, trapped in their residential colleges. Those who were already at home unfortunately forgot to bring along their reference books.

The hectic situation became serious when the government announced that all universities were encouraged to do online learning. Students were required to learn from home and implement the ODL. No one was allowed to conduct face-to face-classes or even interact with each other physically. Lecturers were also asked to do online teaching and work from home. This was to ensure that the higher education system was able to continuously operate and work well on track.

Allam, Hassan, Mohideen, Ramlan and Kamal (2020) described ODL as a teaching method in which students complete their studies anywhere as they are not physically required to come to lecture sessions. It can also be done by fully utilising the internet network (Kenny \& Zhang, 2010) to access lectures easily through a laptop or mobile phone (Hussin, Manap, Amir, \& Krish, 2012). Moreover, there are a lot of stable and free platforms available for lecturers and students to communicate, discuss and conduct the teaching and learning process virtually such as Google Classroom, Google Meet, webinars, TutorRoom, and others.

Many studies have also discovered challenges posed by ODL to students during MCO. Some students are familiar with ODL as they have used it before, but the usage is mixed with face-to-face lectures or consultations. However, during the MCO, students cannot communicate or contact physically with their lecturers. Thus, it creates stress and leads to less motivation and confidence among them (Almaiah, Al-Khasawneh, \& Althunibat, 2020). Another problem is accessibility to internet connection. In Malaysia, the government provides and subsidises $1 \mathrm{~GB}$ data daily to all citizens (Yeoh, 2020). It is a blessing, but some students still cannot access the internet due to their geographical area. This situation gives some challenges to ODL as students are left behind in their studies and are thus not able to excel. Students may be ready to undergo ODL, but the technologies, facilities, and technical skills available are not at a satisfactory level (Allam et al., 2020; Chung, Noor, \& Mathew, 2020; Noraini, Yusuf, \& Ahmad, 2020). Moreover, some students are affected by noisy environments such as disturbance from family members (Sun, Tang \& Zuo, 2020), while some students may use the factor of easy access to the internet to cheat, plagiarise and copy friends' answers for their assessment (Gonzalez et al., 2020; Kearns, 2012; Nizam, Gao, Li, Mohamed, \& Wang, 2020; Timmis, Broadfoot, Sutherland, \& Oldfield, 2016). These situations will trigger negative consequences such as fear of failure and low self-esteem if they remain unchecked, therefore indirectly affecting learning motivation. On the other hand, the efficiency of learning acceptance and accountability of online assessments (Nachmias, 2002) are also in doubt, also contributing to questions on students' overall academic performance.

Thus, due to the challenges ODL pose, this paper tries to discuss the relationship between self-efficacy, learning motivation and performance of higher learning education students to provide deeper understanding among students, lecturers and the faculty management for planning future teaching and course development. 
INTERNATIONAL JOURNAL OF ACADEMIC RESEARCH IN BUSINESS AND SOCIAL SCIENCES Vol. 10, No. 8, 2020, E-ISSN: 2222-6990 @ 2020 HRMARS

\section{Proposed Conceptual Model}

The conceptual model proposed a relationship between students' self-efficacy, learning motivation and academic performance (Figure 1) during the MCO period. This model proposes that students' self-efficacy influences their learning motivation which in turns influence academic performance.

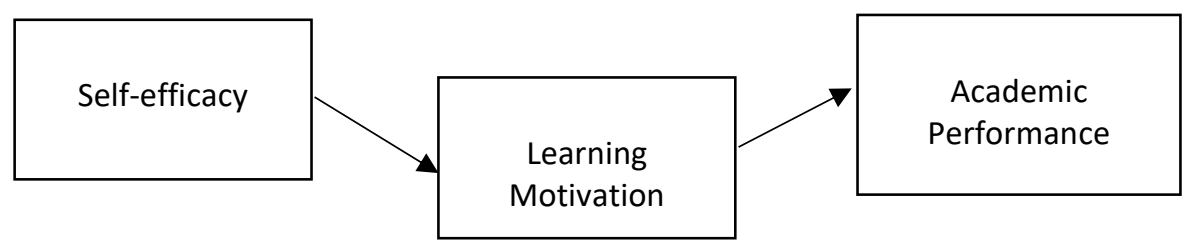

Fig. 1 Student's academic performance conceptual model

Self-efficacy is believed to influence students' motivation (Bandura, 1986, 1997). Students who feel more efficacious should engage more in their thoughts and actions which could enhance their learning motivation despite the difficulties that they face. The more they realise how to react to their goals (excellent academic grades), the higher is their learning motivation. Motivation is a key factor in enhancing any outcome as it postulates individuals' thoughts, beliefs and emotions (Schunk \& Usher, 2012). In this study, learning motivation reacts to the belief of people's capabilities that aspires them in pursuing their academic excellence.

\section{Social Cognitive Theory (SCT)}

The Social Cognitive theory (SCT) (Bandura, 1986) has been widely used to understand and predict human behaviour. This theory in particular postulates on psychological approaches whereby it enables people to interact effectively with social/environmental factors to give personal meaning to their actions as well as their planning, and to implement it in accordance with their goals and standards. It is believed that people learn enormously by acquiring more knowledge, skills, attitudes and others from their environment. This can be done through observation and interaction with others. Basically, Bandura (1986) provided a framework that relates with behaviour and its outcomes by clarifying on the distinctive features of SCT namely self-regulatory and self-reflective capability which humans have to determine their capabilities (Schunk \& Usher, 2012). These capabilities are used to guide humans in making a causal contribution to their outcomes.

Self-regulatory plays an important role in these circumstances. It refers to processes that encourage people to activate and sustain unique behaviours, cognition and effects that are systematically focused on the achievement of goals (Zimmerman, 2000). People will continuously evaluate their task progress to decide on what strategies to use in achieving their respective goals. The motivation to continue progressing in learning is based on their motivation that encourages them to learn. However, SCT also proposes that the interaction depends on environmental conditions. Hence, achieving goals depend on how a person activates and reacts to behaviours, cognition and effects which are influenced by environmental interaction.

The fundamental principle in Bandura's theory is that individuals believe that they can exert a huge amount of influence over important events in their life. Based on this principle, people may 
INTERNATIONAL JOURNAL OF ACADEMIC RESEARCH IN BUSINESS AND SOCIAL SCIENCES Vol. 10, No. 8, 2020, E-ISSN: 2222-6990 @ 2020 HRMARS

give response to decisions according to the priority or importance given through the setting of objectives, preparing of strategies as well as monitoring of goals despite challenges faced. For example, SCT can be applied to understand the concept of online learning even though within the context of the MCO that strictly controls and limits students' freedom in their academic lives and impact their academic performance. Students' learning motivation is determined by their selfefficacy. An individual with high levels of self-efficacy will persist longer against challenges and show resilience in their behaviour. This behaviour will increase their motivation and in turn, influence their academic performance.

\section{Theoretical Background \\ Self-Efficacy}

Self-efficacy refers to an individual's capability to perform required actions to achieve specific goals. Thus, self-efficacy can be understood as a psychological resource that helps individuals cope with a variety of demands (Bandura, 1993) to aim for a certain target. Self-efficacy people control their behaviour through diverse cognitive processes and affective, motivational and decisional practices (Samuel \& Burger, 2019). It influences individuals to behave positively or negatively based on how they perceive opportunities or obstacles. High self-efficacy individuals approach difficult tasks as challenges to be understood; this enhances their commitment rather than avoidance. Meanwhile, those with low sense of efficacy dwell on their competencies as well as their commitments and eventually give up in their efforts.

\section{Learning Motivation}

Learning motivation is defined by Wong, Hwang, Choo and Mohd Ariff (2020) as motivational factors that affect the way students engage and contribute to the classroom learning environment. Student engagement is a key to the creation of learning motivation and students' participation in learning activities (Raza, Qazi \& Umer, 2019). Usually, students with high motivation levels will participate in learning activities without expecting any rewards, but students with low motivation levels need some reward to encourage them to participate in the activities (Skinner \& Belmont, 1993).

Learning motivation can be categorised into intrinsic motivation and extrinsic motivation (Lepper, Corpus \& lyengar et al., 2005; Riswanto \& Aryani, 2017). Riswanto and Aryani (2017) defined intrinsic motivation as the expression of behaviour that is pursued primarily for a person's own pleasure and satisfaction. Moreover, Lepper et al. (2005) stated that intrinsic motivation and academic performance are significantly positive. Students will participate in learning activities just to have fun, feel the challenge without pressure from anybody, and any expectations or rewards (Lepper et al., 2005; Rau, Gao \& Wu, 2008; Ryan \& Deci, 2000). In contrast, (Lin, Chen \& Liu, 2017; Lepper et al., 2005; Rau et al., 2008; Ryan \& Deci, 2000) said that students are classified as having extrinsic motivation if they become motivated only when they receive some reward or is pushed by anyone or anything. However, this situation of extrinsic motivation usually happens only at the initial stage, later it will turn into intrinsic motivation as the learning process continuously goes deeper (Tohidi \& Jabbari, 2012). Both intrinsic and extrinsic motivation play an important role in motivating students when they are in the learning process (Lin et al., 2017; Lepper et al., 2005; Ryan \& Deci, 2000). Since learning is a very challenging process, students need to have the motivation to survive and pursue the learning process to increase their performance (Gopalan, Bakar, Zulkifli, Alwi \& Mat, 2017). 
INTERNATIONAL JOURNAL OF ACADEMIC RESEARCH IN BUSINESS AND SOCIAL SCIENCES Vol. 10, No. 8, 2020, E-ISSN: 2222-6990 @ 2020 HRMARS

\section{Students' Performance}

Student performance can be defined as an outcome of education where students have obtained their educational goals (Makransky et al., 2016). Stemler (2012) further elaborated academic performance as a student's ability to apply the acquired academic knowledge. The results students produce in relation to specific goals that were set up within a particular context (college or university) define a meaningful concept of academic performance amongst higher education students. Therefore, student performance is defined as the academic achievement acquired by meeting the academic criteria set for specific online modules (Fakari et al., 2015).

Despite the fact that the term is widely used within a variety of contexts, the ideology actually entails the results a student achieves in his/her respective modules in which he/she is enrolled. Results can be understood as marks given to students after completing a specific academic task. These tasks usually involve critical thinking, problem solving and knowledge implementing when applied practically. Bodkyn and Stevens (2015) further highlighted the concept by positing that student performance can be measured using some indicators namely student cognition, learning strategies, assessment tools, psychosocial factors, learning environment, self-directed learning, and motivation. For instance, Tinto (1987) took grade point average as the main indicator to measure successful academic achievement, and his work demonstrated a positive relationship between high grade point average and retention. With this notion, the credits obtained from a diploma or degree is a critical function of grades as it signifies that students have earned enough for academic advancement or graduation.

\section{Development of Research Propositions Self-efficacy and Learning Motivation}

In terms of the relationship between self-efficacy and learning motivation, Esmaeili, Sohrabi, Mehryar, and Khayyer (2019) considered academic self-efficacy as a student's ability to challenge academic tasks. As can be seen, self-efficacy affects students' motivation, particularly in the areas of education. Hasanah, Alizamar, Marjohan, and Engkizar (2019) reported a positive correlation between self-efficacy and learning motivation. Such results are compatible with recent studies that indicate that the two variables are strongly positive (Hasanah et al., 2019; Husain, 2014; Drysdale \& McBeath, 2018).

Besides, Burger and Samuel (2017) argued that young people with low self-efficacy are not able to cope with perceived stress in classrooms, thus raising the risk of early withdrawal. In other words, students tend to skip lectures during ODL and ignore the tasks given in the classroom because they personally cannot get support from friends and lecturers. Kheirkhah, Joghi, Jalal, and Haghani (2017) added that disordered motivation may cause conflict with an individual's feelings and contribute to other complications including pessimism, tension, depression, mental health issues and significant deterioration in terms of people's social and professional spheres. Self-efficacy is believed to play an important role in modelling students' actions in ODL during the MCO. Therefore, it is posited that:

Proposition 1: Self-efficacy has an influence on learning motivation. 
INTERNATIONAL JOURNAL OF ACADEMIC RESEARCH IN BUSINESS AND SOCIAL SCIENCES Vol. 10, No. 8, 2020, E-ISSN: 2222-6990 @ 2020 HRMARS

\section{Learning Motivation and Student Performance}

Previous research has shown the significant relationship between learning motivation and student performance (Bank \& Finlapson, 1980; Ajayi, 1999; Ayub, 2010). These researchers have successfully found evidence that highly motivated students perform better academically compared to students with lower motivation. It is believed that a student's reaction to education will determine the extent to which he/she performs in online learning. In fact, the issues of motivation amongst students in higher education and the impact on their academic performance are deemed to be pivotal for effective ODL, especially during the MCO period. In other words, motivation itself acts as a necessary ingredient for learning and academic efficiency. Therefore, it is anticipated that:

Proposition 2: Students' learning motivation is highly correlated to their academic performance.

\section{Self-efficacy, Motivation and Student Performance}

It is proposed that self-efficacy will have significant impact on learning motivation as well as student performance. Presumably, self-efficacy alone cannot directly influence student performance, at least not when learning is undertaken remotely and on digital platforms. Thus, it is contended that learning motivation will mediate the relationship between self-efficacy and student performance.

ODL has become the cornerstone of many institutions of higher education since the COVID19 outbreak. Given that ODL is the only logical option for now, it is feared that this approach will have stumbling blocks such as technical difficulties, students who experience isolation and accessibility issues. In fact, ODL requires students to take more responsibility for learning, thus transforming them from passive to active learners. According to Jacob and Radhai (2016), students need more motivation and discipline in order for them to be successful. Another striking point was derived from a study by Jian (2019) on the effect of digital flipped classroom teaching which claimed that cultivating students' positive behaviour towards independent learning induces students' learning motivation as well as allows for educators' individualised instruction to effectively enhance the overall learning performance. The finding was supported by Park, Park, and Chae (2018) who indicated that students in digital flipped classrooms possess higher academic achievement with lower cognitive load levels. The results show that online learning requires definite objectives, inner motive and student independence.

Based on the above aforementioned facts, it was found that motivation has emerged as an important predictor of variables impacting students' performance (Bodkyn \& Stevens, 2015). In this realm, Walberg, Fraser and Welch (1986) through their meaningful research explained the linkages between learning variables and student performance, and found motivation as one of the key variables that strongly influence students' performance. This study discusses an important claim which asserts that motivation has a significant direct influence on students' performance. Ayub (2010) who performed a study on 200 students from different colleges in Karachi, Pakistan also found the same evidence to support previous research findings suggesting learning motivation as an essential element of more meaningful learning especially during critical moments such as the MCO.

In this sense, a meta-analysis performed by Robbins et al. (2004) confirmed the strong relationship between self-efficacy and motivation amongst students in American colleges. 
Additionally, evidence from Yusuf (2011) showed the direct effect of self-efficacy and indirect influence of motivation on academic performance. The above findings were similar to existing literature on self-efficacy and motivation in relation to students' academic achievement (Elias, Mahyuddin, Noordin, Abdullah, \& Roslan, 2009; Joo, Bong \& Choi, 2000). From this basis, it is highlighted that good efficacy of beliefs with clear perceptions of a task with values and learning interest will substantially empower students' learning motivation and influence their learning performance. In general, students with a high level of self-efficacy are more likely to make efforts to complete a task and are more motivated and confident than those with low self-efficacy. This will simultaneously enhance the students' overall academic efficiency. Based on these facts, it is predicted that:

Proposition 3: Learning motivation mediates the relationship between self-efficacy and student performance.

\section{Conclusion}

ODL during $\mathrm{MCO}$ is a new normal where learning and teaching depend on the internet and technological and communication facilities such as mobile phones and laptops. Hundreds of universities and education institutes are turning to online learning for very valid reasons. Even though it creates a lot of challenges and is hectic, as time goes by, ODL becomes more comfortable and manageable. This discussion shows that there are three propositions related to self-efficacy, learning motivation and students' performance. The first proposition is that self-efficacy influences learning motivation. It is supported by previous studies showing positive correlations between the two variables. The second proposition is that students' learning motivation is highly correlated to their academic performance. This proposition shows that learning motivation plays an important role in increasing students' academic performance. The third proposition is that learning motivation mediates the relationship between self-efficacy and student performance. Earlier discussion showed a strong relationship between these three variables. However, self-efficacy alone cannot directly influence students' performance. It needs motivation as a mediator. In the case of MCO, ODL becomes a challenge to students as they face difficulties in accessibility, incomplete online facilities and environmental disturbance. These situations will lead students to increase their motivation and discipline to be successful.

\section{Theoretical and Contextual Contribution}

This study has proposed a conceptual model based on The Social Cognitive theory (SCT) (Bandura, 1986) in understanding the students' behaviour. The conceptual model will serve as a basis for developing a learning evaluation tool to understand the effectiveness of implementing ODL among students. It also provides a framework to understand on how students may use their self-efficacy in applying positive learning motivation to increase their academic performance.

This study suggested a mediating role of learning motivation between students' self-efficacy and their academic performance. The findings were similar and significant to the existing literature on selfefficacy and learning motivation on student's academic performance (Hasanah et al., 2019; Husain, 2014; Drysdale \& McBeath, 2018; Bank \& Finlapson, 1980; Ajayi, 1999; Ayub, 2010; Elias et al., 2009; Joo et al., 2000). However, a systematic analysis based on ODL learning effects during MCO is still 
INTERNATIONAL JOURNAL OF ACADEMIC RESEARCH IN BUSINESS AND SOCIAL SCIENCES Vol. 10, No. 8, 2020, E-ISSN: 2222-6990 @ 2020 HRMARS

limited. Therefore, this study provides a theoretical basis for understanding more on the students' behaviour in the context of unusual study environment.

It is also significant for the parents to understand on their children study behavior which may highly related to the way on how self-efficacy might influence their learning motivation. Furthermore, this study advances our understanding on how students behave towards their learning process during MCO. The implementation of ODL during the MCO may affect students' learning outcomes due to the challenges faced and the restricted conditions posed by the government. This contribution could also be beneficial to lecturers and the faculty management in designing new online course features which, can help students to excel in their studies. The propositions will extend understanding on the important relationship between self-efficacy, learning motivation and students' performance in the context of ODL. It also provides many opportunities to fulfil responsibilities in improving the ODL learning platform to be more user friendly.

\section{Corresponding Author}

Hasnizawati Hashim (Dr), hasnizawati@uitm.edu.my, Faculty of Business \& Management, Universiti Teknologi MARA Pahang, Raub Campus, 27600 Raub, Pahang.

\section{References}

Ajayi, I. A. (1999). Analysis of Teachers' Job Performance and Secondary School Students Achievement and their Relationship. African Journal of Educational Research, 5(2), 85 - 98.

Allam, S. N. S., Hassan, M. S., Mohideen, R. S., Ramlan, A. F., \& Kamal, R. M. (2020). Online Distance Learning Readiness During Covid-19 Outbreak Among Undergraduate Students. International Journal of Academic Research in Business and Social Sciences, 10(5), 575-590. http://dx.doi.org/10.6007/IJARBSS/v10-i5/7236

Almaiah, M. A., Al-Khasawneh, A., \& Althunibat, A. (2020). Exploring the critical challenges and factors influencing the E-learning system usage during COVID-19 pandemic. Education and Information Technologies. https://doi.org/10.1007/s10639-020-10219-y

Ayub, N. (2010). Effect of intrinsic and extrinsic motivation on academic performance. Pakistan business review, 8, 363-372.

Bandura, A. (1986). Social foundations of thoughts and action: A social cognitive theory. Englewood Cliffs. NJ: Prentice Hall

Bandura, A. (1993). Perceived self-efficacy in cognitive development and functioning. Educational Psychologist, 28(2), 117-148.https://doi.org/10.1207/s15326985ep2802_3

Bandura, A. (1997). Self-efficacy: The exercise of control. New York: Freeman

Bank, C., and Finlapson, W. (1980). Successful Motivation of Students in Academic Activities in McClelland, D.C. Appleton-Century-Crafts.

Bodkyn, C., \& Stevens, F. (2015). Self-directed learning, intrinsic motivation and student performance. The Caribbean Teaching Scholar, 5(2).

Burger, K., \& Samuel, R. (2017). The role of perceived stress and self-efficacy in young people's life satisfaction: A longitudinal study. Journal of youth and adolescence, 46(1), 78-90. https://doi.org/10.1007/s10964-016-0608-x

Chung, E., Noor, N. M., \& Mathew, V. N. (2020). Are You Ready? An Assessment of Online Learning Readiness among University Students. International Journal of Academic Research in Business 
INTERNATIONAL JOURNAL OF ACADEMIC RESEARCH IN BUSINESS AND SOCIAL SCIENCES Vol. 10, No. 8, 2020, E-ISSN: 2222-6990 @ 2020 HRMARS

and Social Sciences, 9(1), 301-317. https://doi.org/10.6007/IJARPED/v9-i1/7128

Coronavirus disease (COVID-19) in Malaysia. (2020). https://www.who.int/malaysia

Drysdale, M. T., \& McBeath, M. (2018). Motivation, self-efficacy and learning strategies of university students participating in work-integrated learning. Journal of Education and Work, 31(5-6), 478-488.

Elias, H., Mahyuddin, R., Noordin, N., Abdullah, M. C., \& Roslan, S. (2009). Self-Efficacy Beliefs of AtRisk Students in Malaysian Secondary Schools. International Journal of Learning, 16(4).

Esmaeili, L., Sohrabi, N., Mehryar, A. H., \& Khayyer, M. (2019). A Causal Model of Motivational Beliefs with the Mediating Role of Academic Hope on Academic Self-Efficacy in High School Students. Iranian Evolutionary and Educational Psychology Journal, 1(3), 179-185.

Fakari, F. R., Kordi, M., Mazloom, S. R., Khadivzadeh, T., Tara, M., \& Akhlaghi, F. (2015). Comparing the effect of traditional, web based and simulation training on midwifery students' clinical competence in postpartum hemorrhage management. Journal of Mazandaran University of Medical Sciences, 25(123), 65-77.

Gonzalez, T., de la Rubia, M. A., Hincz, K. P., Comas-Lopez, M., Subirats, L., Fort, S., \& Sacha, G. M. (2020). Influence of COVID-19 confinement in students performance in higher education. 125. http://arxiv.org/abs/2004.09545

Gopalan, V., Bakar, J. A. A., Zulkifli, A. N., Alwi, A., \& Mat, R. C. (2017). A review of the motivation theories in learning. AIP Conference Proceedings, 1891 (October 2017). https://doi.org/10.1063/1.5005376

Hasanah, U., Alizamar, A., Marjohan, M., \& Engkizar, E. (2019). The Effect of Self Efficacy and Parent Support on Learning Motivation in Management Business Students in Padang's Private Vocational School. KONSELI: Jurnal Bimbingan dan Konseling (E-Journal), 6(2), 133-140.

Husain, U. K. (2014). Relationship between self-efficacy and academic motivation. In International Conference on Economics, Education and Humanities (ICEEH'14) (pp. 10-11).

Hussin, S., Manap, M. R., Amir, Z., \& Krish, P. (2012). Mobile learning readiness among Malaysian students at higher learning institutes. Asian Social Science, 8(12), 276-283. https://doi.org/10.5539/ass.v8n12p276

Jacob, S., \& Radhai, S. (2016). Trends in ICT e-learning: Challenges and expectations. International Journal of Innovative Research \& Development, 5(2), 196-201.

Jian, Q. (2019). Effects of digital flipped classroom teaching method integrated cooperative learning model on learning motivation and outcome. The Electronic Library. https://doi.org/10.1108/EL-02-2019-0024.

Joo, Y. J., Bong, M., \& Choi, H. (2000). Self-efficacy for self-regulated learning, academic self-efficacy, and Internets self-efficacy in web-based. Educational Technology, Research and Development, 48(2) 5-17

Kearns, L. (2012). Student Assessment in Online Learning: Challenges and Effective Practices. Jolt.Merlot.Org, 8(3), 198-208. http://jolt.merlot.org/vol8no3/kearns_0912.htm

Kenny, R. F., \& Zhang, Z. (2010). Learning in an Online Distance Education Course : Experiences of Three International Students. International Review of Research in Open and Distance Learning, 11(1), 17-36.

Kheirkhah, M., Joghi, Z. Z., Jalal, E. J., \& Haghani, H. (2017). The relationship between self-efficacy and motivation among midwifery students of Tehran University of Medical Sciences in 2016. Der Pharmacia Lettre, 9(1), 29-37. 
INTERNATIONAL JOURNAL OF ACADEMIC RESEARCH IN BUSINESS AND SOCIAL SCIENCES

Vol. 10, No. 8, 2020, E-ISSN: 2222-6990 @ 2020 HRMARS

Khor, V., Arunasalam, A., Azli, S., Khairul-Asri, M. G., \& Fahmy, O. (2020). Experience from Malaysia During the COVID-19 Movement Control Order. Urology, 1-2. https://doi.org/10.1016/j.urology.2020.04.070

Lepper, M. R., Corpus, J. H., \& lyengar, S. S. (2005). Intrinsic and extrinsic motivational orientations in the classroom: Age differences and academic correlates. Journal of Educational Psychology, 97(2), 184-196. https://doi.org/10.1037/0022-0663.97.2.184

Lin, M. H., Chen, H. C., \& Liu, K. S. (2017). A study of the effects of digital learning on learning motivation and learning outcome. Eurasia Journal of Mathematics, Science and Technology Education, 13(7), 3553-3564.

Makransky, G., Bonde, M. T., Wulff, J. S., Wandall, J., Hood, M., Creed, P. A., Bache, I., Silahtaroglu, A., \& Nørremølle, A. (2016). Simulation based virtual learning environment in medical genetics counseling: an example of bridging the gap between theory and practice in medical education. BMC medical education, 16(1), 1-9.

Nachmias, R. (2002). A research framework for the study of a campus-wide Web-based academic instruction project. The Internet and higher education, 5(3), 213-229. https://doi.org/10.1016/S1096-7516(02)00103-3

Nizam, N. I., Gao, S., Li, M., Mohamed, H., \& Wang, G. (2020). Scheme for Cheating Prevention in Online Exams during Social Distancing. Preprints, April. https://doi.org/10.20944/PREPRINTS202004.0327.V1

Noraini, B., Yusuf, M., \& Ahmad, J. (2020). Are we Prepared Enough ? A Case Study Of Challenges In Online Learning In A Private Higher Learning Institution During The Covid-19 Outbreaks. 7(5), 205-212. https://doi.org/10.14738/assrj.75.8211.

Park, K. H., Park, K. H., \& Chae, S. J. (2018). Experiences of medical teachers in flipped learning for medical students: a phenomenological study. Korean journal of medical education, 30(2), 91. https://doi.org/10.3946/kjme.2018.84.

Rau, P. L. P., Gao, Q., \& Wu, L. M. (2008). Using mobile communication technology in high school education: Motivation, pressure, and learning performance. Computers and Education, 50(1), 1-22. https://doi.org/10.1016/j.compedu.2006.03.008.

Raza, S. A., Qazi, W., \& Umer, B. (2019). Examining the impact of case-based learning on student engagement, learning motivation and learning performance among university students. Journal of Applied Research in Higher Education, 12(3), 517-533. https://doi.org/10.1108/JARHE-05-2019-0105.

Riswanto, A., \& Aryani, S. (2017). Learning motivation and student achievement : description analysis and relationships both. COUNS-EDU: The International Journal of Counseling and Education, 2(1), 42. https://doi.org/10.23916/002017026010.

Robbins, S. B., Lauver, K., Le, H., Davis, D., Langley, R., \& Carlstrom, A. (2004). Do Psychosocial and Study Skill Factors Predict College Outcomes? A Meta-Analysis. Psychological Bulletin, 130(2), 261-288. https://doi.org/10.1037/0033-2909.130.2.261.

Ryan, R. M., \& Deci, E. L. (2000). Intrinsic and extrinsic motivations: Classic definitions and new directions. Contemporary educational psychology, 25(1), 54-67.

https://doi.org/10.1006/ceps.1999.1020.

Samuel, R., \& Burger, K. (2019). Negative life events, self-efficacy and social support: Risk and protective factors for school dropout intentions and dropout. Journal of Educational Psychology. https://dx.doi.org/10.1037/edu0000406. 
INTERNATIONAL JOURNAL OF ACADEMIC RESEARCH IN BUSINESS AND SOCIAL SCIENCES Vol. 10, No. 8, 2020, E-ISSN: 2222-6990 @ 2020 HRMARS

Schunk, D. H., \& Usher, E. L. (2012). Social cognitive theory and motivation. https://dx.doi.org/10.1093/oxfordhb/9780195399820.013.0002.

Skinner, E. A., \& Belmont, M. J. (1993). Motivation in the classroom: Reciprocal effects of teacher behavior and student engagement across the school year. Journal of educational psychology, 85(4), 571. https://doi.org/10.1037/0022-0663.85.4.571.

Stemler, S. E. (2012). What should university admissions tests predict? Educational Psychologist, 47(1), 5-17. https://doi.org/10.1080/00461520.2011.61144

Sun, L., Tang, Y., \& Zuo, W. (2020). Coronavirus pushes education online. Nature Materials, 19(June), 2020. https://doi.org/10.1038/s41563-020-0678-8.

Timmis, S., Broadfoot, P., Sutherland, R., \& Oldfield, A. (2016). Rethinking assessment in a digital age: opportunities, challenges and risks. British Educational Research Journal, 42(3), 454-476. https://doi.org/10.1002/berj.3215.

Tinto, V. (1987). Leaving college: Rethinking the causes and cures of student attrition. University of Chicago Press, 5801 S. Ellis Avenue, Chicago, IL 60637.

Tohidi, H., \& Jabbari, M. M. (2012). The effects of motivation in education. Procedia - Social and Behavioral Sciences, 31(2011), 820-824. https://doi.org/10.1016/j.sbspro.2011.12.148.

Walberg, H. J., Fraser, B. J., \& Welch, W. W. (1986). A test of a model of educational productivity among senior high school students. The Journal of Educational Research, 79(3), 133-139. https://doi.org/10.1080/00220671.1986.10885664.

Wong, K. T., Hwang, G. J., Choo, G. P. S., \& Arrif, M. S. K. (2020). Effects of blended learning pedagogical practices on students' motivation and autonomy for the teaching of short stories in upper secondary English. Interactive Learning Environments, 28(4), 512-525. https://doi.org/10.1080/10494820.2018.1542318.

Yeoh, A. (2020). MCO: Telcos to offer free $1 \mathrm{~GB}$ data daily from April 1, here's what you should know. The Star.

Yusuf, M. (2011). The impact of self-efficacy, achievement motivation, and self-regulated learning strategies on students' academic achievement. Procedia-Social and Behavioral Sciences, 15, 2623-2626. https://doi.org/10.1016/j.sbspro.2011.04.158.

Zimmerman, B. J. (2000). Attaining self-regulation: A social cognitive perspective. New York: Academic Press. 